\title{
ERRATUM
}

\section{Erratum to: Retrospective Analysis of First-Line Anti-Vascular Endothelial Growth Factor Treatment Patterns in Wet Age-Related Macular Degeneration}

Stephen S. Johnston • Kathleen Wilson • Alice Huang •

David Smith $\cdot$ Helen Varker $\cdot$ Adam Turpcu

To view enhanced content go to www.advancesintherapy.com

Published online: January 18, 2014

(c) The Author(s) 2014. This article is published with open access at Springerlink.com

Erratum to: Adv Ther (2013) 30:1111-1127

DOI 10.1007/s12325-013-0078-4

The authors would like to make the following adjustments to the above mentioned article. In the original manuscript figure 3 is incorrect, the correct version is attached below (Fig. 3). The figure in appendix was not included. It is shown here below (appendix figure 1). Both figure legends are correct in the main article.
The online version of the original article can be found under doi:10.1007/s12325-013-0078-4.

S. S. Johnston $(\bowtie) \cdot$ K. Wilson · A. Huang ·

D. Smith $\cdot$ H. Varker

Truven Health Analytics, 7700 Old Georgetown Rd, Ste 650, Bethesda, MD 20814, USA

e-mail: stephen.johnston@truvenhealth.com

A. Turpcu

Genentech, Inc., 1 DNA Way, South San Francisco,

CA 94080, USA
Open Access. This article is distributed under the terms of the Creative Commons Attribution Noncommercial License which permits any noncommercial use, distribution, and reproduction in any medium, provided the original author(s) and the source are credited. 


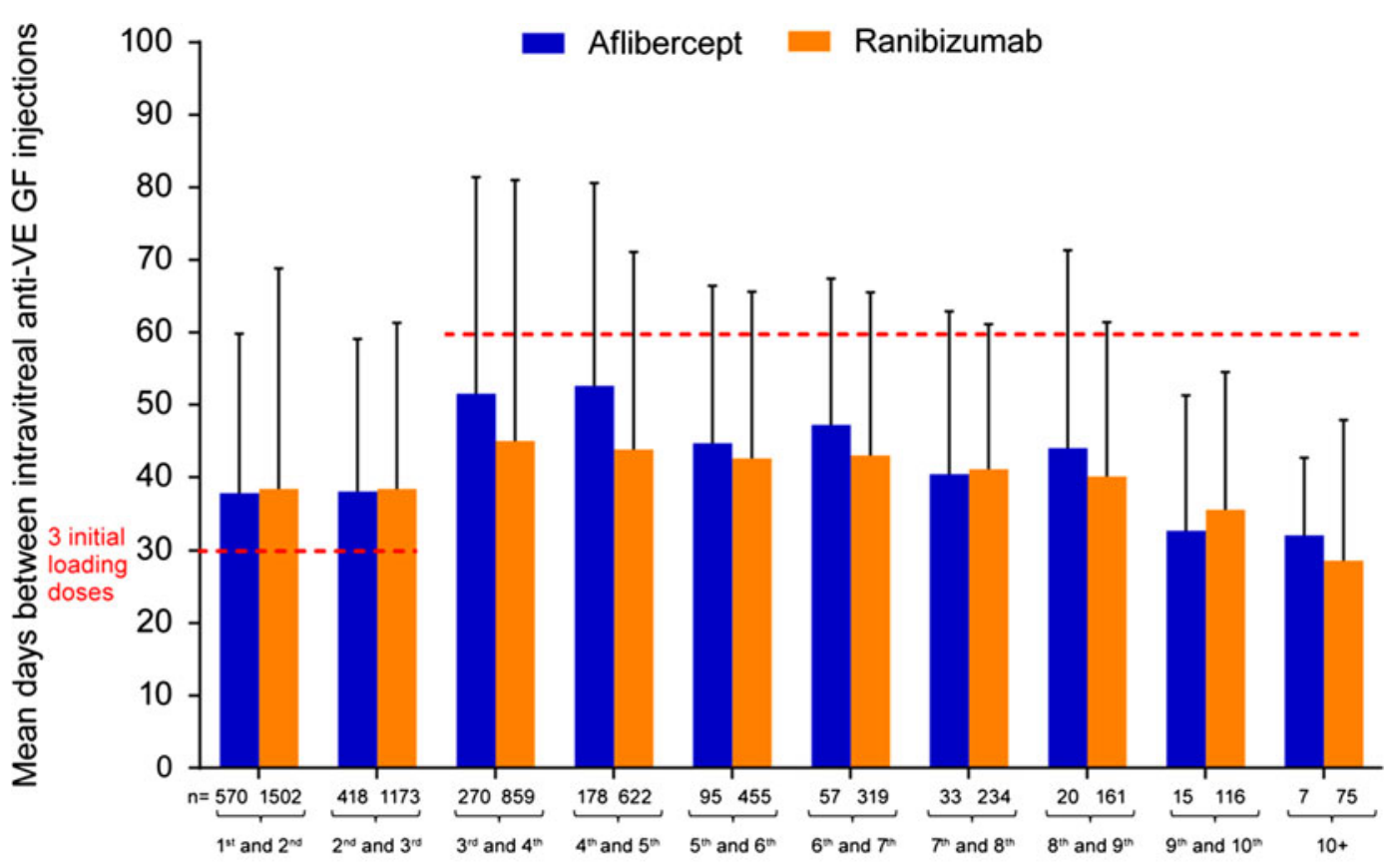

Figure 3

Interval between procedures

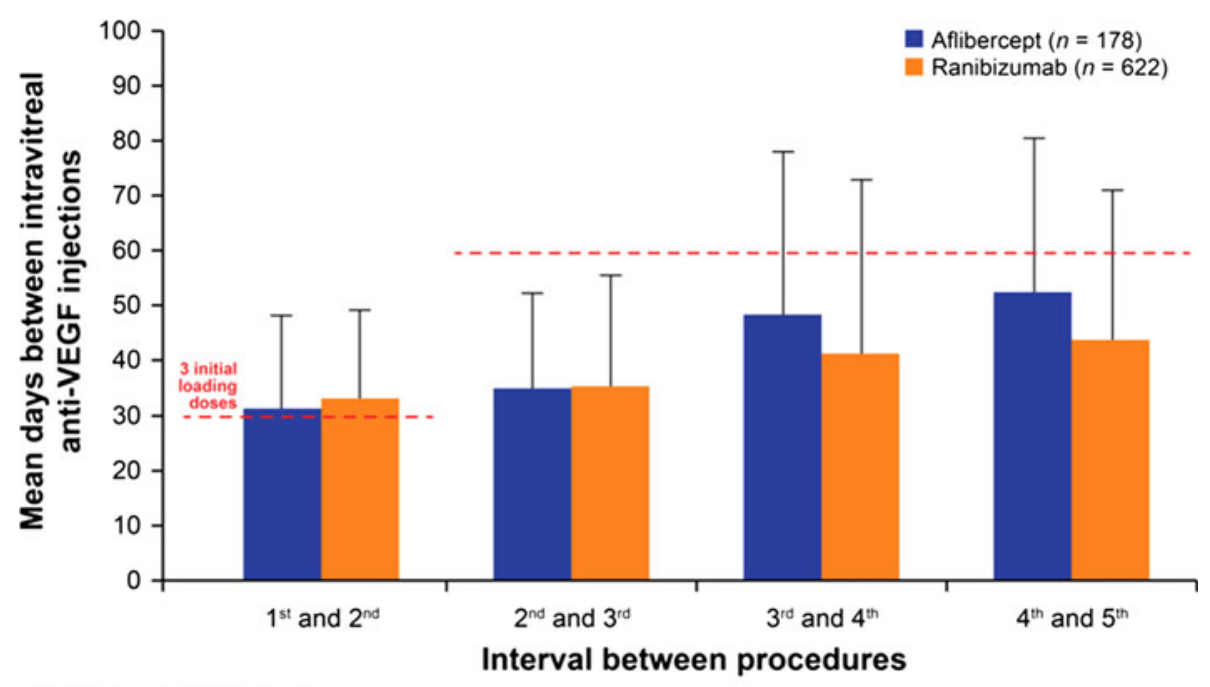

Appendix figure 1 